\title{
ON THE DIAGNOSTIC TERM “DOWN'S DISEASE”
}

\author{
by
}

\section{NORMAN HOWARD-JONES*}

UNTIL VERY recent years the genetically determined condition now generally known as Down's disease or syndrome had been known for about a century as "mongolism" or "mongolian imbecility", and it is perhaps of some interest to recall how it acquired both this and its present designation.

In 1866 a London physician, John Langdon Haydon Down (1828-1896), ${ }^{1}$ published a paper entitled 'Observations on an ethnic classification of idiots'. ${ }^{2}$ In this he started by pointing to the lack of a satisfactory classification of "congenital mental lesions". He suggested that a "natural system" of classifying "the feeble-minded" might be achieved by "arranging them around various ethnic standards", as "a considerable proportion can be fairly referred to one of the great divisions of the human race other than the class from which they have sprung". The divisions to which Down referred were the five of the ethnographic classification that had been proposed by Johann Friedrich Blumenbach in a dissertation presented for a doctorate of medicine of the University of Göttingen on 16 September $1775 .^{3}$

Down had no lack of subjects for study, as he was the Medical Superintendent of the Earlswood Asylum for Idiots, ${ }^{4}$ whom he tried to classify by reference to a supposed facial resemblance to each of Blumenbach's ethnic groups. First came, according to Down, those who resembled the "great Caucasian family". ${ }^{5}$ Next came "several well-marked examples of the Ethiopian [i.e. African] variety", followed by the "Malay variety", those resembling the "people . . . who originally inhabited the American Continent", 6 and finally those whose facies suggested the "great Mongolian family" more than any of the other great divisions of mankind. It should be recalled that *Norman Howard-Jones O.B.E., M.R.C.S., L.R.C.P., 28 Chemin Colladon, 1209 Geneva, Switzerland.

1 He later changed his name to John Langdon Haydon Langdon-Down.

2 Lond. Hosp. clin. Lect. Rep., 1866, 3: 259-262.

8 As would be expected, Blumenbach's dissertation was in Latin, and in the third edition of Leslie T. Morton's Garrison and Morton's medical bibliography (London, Deutsch, 1970) its title is given as De generis humani varietate nativa. I have used a partial translation by Thomas Bendysshe of the "third and much revised edition (1795)" reproduced by Earl W. Count as editor of This is race. An anthology selected from the international literature on the races of man, New York, Schuman, 1950. The partial reproduction of Blumenbach's 'Section IV. Five Principal Varieties of Mankind, One Species' is on pages 34-39 of this very useful anthology.

4 G. H. Brown, Lives of the Fellows of the Royal College of Physicians 1826-1925, London, Royal College of Physicians, 1955. In keeping with the preference of our time for euphemisms, this establishment is now known as the Royal Earlswood Hospital, and is at Redhill, Surrey. But it is still an asylum for idiots.

s It was Blumenbach who introduced the word "Caucasian" as an ethnographic term: "I have taken the name of this variety from Mount Caucasus ... because its neighbourhood .... produces the most beautiful race of man, I mean the Georgian."

- In fact, Blumenbach said, too elliptically: "This variety comprehends the inhabitants of America 


\section{Short Articles}

Blumenbach's "Mongolian family" included almost the entire population of east Asia.

Down devoted particular attention to the last group-probably because its characteristics were sufficiently constant and often encountered to make it an easily recognizable clinical entity. He attributed most cases of the "Mongolian type of idiocy" (he did not use the term "mongolism") to "tuberculosis in the parents", which he believed to be the "hereditary origin of the degeneracy". Down's ethnic classification contained no implication of an evolutionary hierarchy of ethnic characteristics, for among the "large number of idiots and imbeciles"" that he had studied he found "numerous representatives" both of the "great Caucasian family" and the "great Mongolian family", the "Ethiopian", "Malay", and "American" varieties being much fewer.

As a general conclusion, Down wrote: "I cannot but think that the observations which I have recorded are indications that the differences in the races are not specific but variable." In a final sentence he stated : "These examples of the result of degeneracy among mankind appear to me to furnish some arguments in favour of the unity of the human species."

The term "mongolism" existed for more than a hundred years-and still sometimes exists-as a relic of Down's attempt to classify mental defectives by reference to Blumenbach's ethnographic classification, although it is obviously as unscientific as it is unacceptable for other reasons. It should be noted that there is no suggestion in Down's paper that Blumenbach's ethnic Mongolians were more susceptible to mental defect than other ethnic groups.

To determine what was the first example of the use of Down's disease or syndrome would be an undertaking as laborious as it would be of questionable utility, but "Mongolism" persisted as the descriptor in Medical subject headings until 1975, when it was replaced by "Down's syndrome".

In the first year of the new Index medicus in 1960, the articles listed provided only an occasional example of the use of the eponymic designation in preference to "mongolism". In the following year the Lancet published a letter from nineteen signatories, including W. Langdon-Down and L. S. Penrose, urging that the term "mongolism" should be abandoned in favour of "Langdon-Down's anomaly", "Down's syndrome or anomaly", "congenital acromicria", or "trisomy 21 anomaly". The signatories -eight of them American, five British, two French, and one each Danish, Japanese, Swedish, and Swiss pointed out that "the increasing participation of Chinese and Japanese investigators in the study of the condition imposes on them the use of an embarrassing term."8. Later in the year, letters from two correspondents in the same journal deplored the use of the term "Down's syndrome" in two articles. ${ }^{9}$ An editorial

except the Esquimaux". (Blumenbach, op. cit., note 3 above, p. 35.) The order in which Blumenbach enumerated his "varieties" was Mongolian, Ethiopian, American, Malay, and "Caucasian".

'In a paper on 'Marriages of consanguinity in relation to degeneration of race', Lond. Hosp. clin. Lect. Rep., 1866, 3: 224-236, Down refers to "1183 cases of idiots" studied.

${ }^{8}$ Gordon Allen, C. E. Benda, J. A. Böök, C. O. Carter, C. E. Ford, E. H. Y. Chu, E. Hanhart, George Jervis, W. Langdon-Down, J. Lejeune, Hideo Nishimura, J. Oster, L. S. Penrose, P. E. Polani, Edith L. Potter, Curt Stern, R. Turpin, J. Warkany, Herman Yannet, Lancet, 1961, i: 775.

J. M. K. Spalding, Lancet, 1961, ii: 935; M. H. Pappworth, ibid. 


\section{Short Articles}

note, misquoting the title of Down's paper, explained that "mongolism" had "misleading racial connotations and is hurtful to many parents"!! However, it was not until its second 1964 volume that the Lancet indexed the condition under its eponymic designation.

In 1965, the Eighteenth World Health Assembly awarded L. S. Penrose a prize for his contributions to the understanding of mental subnormality-notably, in the words of the President of the Assembly, of "mongolism" and "the Klinefelter mongol".10 By then, the Mongolian People's Republic had been a member of the World Health Organization for three years, and the Mongolian delegation informally requested the WHO Director-General that these objectionable terms should in future be avoided. ${ }^{11}$ Henceforth they disappeared from WHO publications.

In 1969 Batchelor pointed out that the resemblance of so-called "mongols" to ethnic Mongolians was superficial, and that "the physiognomy of the mongol can still be recognized when the individual is Mongolian by race", 12 as had previously been stated by the nineteen signatories of the 1961 letter. That this should be so removes any shadow of justification for retaining the term "mongolism".

10 Official records of the World Health Organization, 1965, 144: 98.

11 Personal recollection as erstwhile Director of the Division of Editorial and Reference Services of the World Health Organization.

12 Ralph Campbell Batchelor. Henderson and Gillespie's textbook of psychiatry, 10th ed., London, Oxford University Press, 1969.

\section{News, Notes and Queries}

\section{FIFTIETH ANNIVERSARY OF THE OSLER CLUB OF LONDON}

THE OSLER Club of London first met on 28 April 1928. It was founded by two Bart's medical students who wished to honour the memory of Osler and to start a club of which Sir William himself would have liked to have been a member. Now the Club has members from many countries. It meets regularly in London, sometimes out of town, and on rare occasions in other countries. Oxford, of course, has a special place in the Club's affections and it was appropriate that the fiftieth anniversary was celebrated there on Rogation Sunday, 30 April 1978.

At 11 a.m. on a grey, damp morning members attended matins in the church at Ewelme. The President, Dr. Neil McIntyre, read the first lesson (Ecclesiasticus, chapter 44 ) beginning with the words, "Let us now remember famous men ...". The Rector, the Rev. Ivor Williams, heeded these words and in particular reminded members and his parishioners of Osler's efforts on behalf of the Church and the neighbouring Almshouses at Ewelme. As Regius Professor of Medicine at Oxford, Osler was Master of Ewelme Almshouses. He stayed there often and played a great part in the life of the village. 